\title{
Characteristics and retention of luteal structures, extended postinsemination cycle, progesterone, and pregnancy-specific protein B in serum after human chorionic gonadotropin treatment of dairy cows ${ }^{1}$
}

\author{
J. S. Stevenson ${ }^{2}$ and S. L. Pulley \\ Department of Animal Sciences and Industry, Kansas State University, Manhattan 66506-0201
}

\begin{abstract}
Our objectives were to determine characteristics (size, number, and stayability) of luteal structures formed in response to human chorionic gonadotropin (hCG) administered on d 7 after timed artificial insemination (AI) and the influence of $\mathrm{hCG}$ on returns to estrus and pregnancy outcome. Holstein cows $(\mathrm{n}=$ 328 ), milked 3 times daily, previously inseminated at first service were assigned randomly to a completely randomized design consisting of 2 treatments when at least 1 corpus luteum (CL) was detected on d 7 after AI. Treatment consisted of 1,000 IU hCG or $1 \mathrm{~mL}$ of saline (control) administered i.m. Blood was collected and luteal structures were mapped and sized by transrectal ultrasonography on d 7, 14, 21, 28, and 32 after AI. Blood also was collected on d 60 in all pregnant cows. Treatment with hCG induced new luteal structures in $70 \%$ of cows, regardless of pregnancy status or number of pretreatment CL. Cows producing greater than the median $46 \mathrm{~kg}$ of energy-corrected milk per day were less likely to respond to hCG. The number of total luteal structures per cow, original CL volume, and total luteal volume (original CL + new luteal structures) were increased by hCG. Progesterone concentration was greater in pregnant than nonpregnant cows on $\mathrm{d} 14$ unless cows responded to hCG by forming new luteal structures. Concentrations of progesterone were greatest in pregnant, hCG-treated cows. Pregnancy per AI at d 32 or 60 after first AI was less in hCG- than salinetreated cows because pregnancy outcome for hCG cows that had only 1 pretreatment CL and failed to respond to hCG was only 55 to $61 \%$ of that observed in controls. Proportions of cows returning to estrus from 18 to $25 \mathrm{~d}$ after AI were less in hCG than control cows but greater
\end{abstract}

\footnotetext{
Received December 21, 2011.

Accepted April 7, 2012.

${ }^{1}$ Contribution number 12-244-J from the Kansas Agricultural Experiment Station, Manhattan 66506.

${ }^{2}$ Corresponding author: jss@k-state.edu
}

for cows returning $>25 \mathrm{~d}$. Regardless of treatment, $25 \%$ of cows in both treatments retained at least 1 original CL to d 28 after AI and were not pregnant on d 32. Progesterone concentrations in these nonpregnant cows with retained CL between d 14 and 28 after AI were intermediate between nonpregnant cows that returned to estrus by d 25 and all pregnant cows. Concentrations of pregnancy-specific protein B were elevated in some of these nonpregnant, CL-retained cows, indicating early pregnancy loss. Retention of original luteal tissue in nonpregnant cows to d 28 after AI indicated that pregnancy had been initiated but failed, as verified by concentrations of progesterone and pregnancy-specific protein B.

Key words: human chorionic gonadotropin, corpus luteum, progesterone, pregnancy-specific protein B

\section{INTRODUCTION}

Luteal structure(s) (corpus luteum or corpora lutea; CL) that form after ovulation of bovine ovarian follicles are critical for facilitating pregnancy because they secrete progesterone, which is essential to development of the conceptus and future pregnancy recognition (Mann and Lamming, 1999). Conception failure is coincident with less-than-normal concentrations of progesterone as early as d 6 after insemination (Thatcher et al., 2001). In general, blood concentrations of progesterone rise earlier and achieve greater concentrations in pregnant than in nonpregnant cows (Thatcher et al., 2001). Progesterone stimulates normal embryo development (Thatcher et al., 1994) and the ability of the conceptus to secrete the antiluteolytic signal IFN- $\tau$ (Mann et al., 1999).

A meta-analysis of 17 progesterone-supplementation studies indicated that treatment during the first week after AI enhanced conception rates but had little or no effect when administered during the second or third weeks after AI (Mann and Lamming, 1999). Several treatments have been used to increase peripheral concentrations of progesterone after AI, including those that increase endogenous function of the existing CL, 
induce accessory luteal structures, or supplement progestin or progesterone directly (Stevenson et al., 2007).

In recent years, human chorionic gonadotropin (hCG) has been evaluated for its ability to improve bovine fertility by altering ovarian function. Human chorionic gonadotropin has activity similar to $\mathrm{LH}$, is able to bind to tissue LH receptors, and mimics the effects of $\mathrm{LH}$ by causing small luteal cells to increase progesterone synthesis (Niswender et al., 1985; 2000). When given early in the estrous cycle (d 3 to 5 ; d 0 = estrus), hCG can alter the proportions of small and large luteal cells in ewes (Farin et al., 1988), thus potentially changing total progesterone production by the CL, because approximately $80 \%$ of luteal progesterone is derived from large luteal cells (Niswender et al., 2000). When administered during the mid-luteal phase (d 10 to 15 ), hCG alters the duration of the estrous cycle (Eduvie and Seguin, 1982; Howard and Britt, 1990) and enhances endogenous concentrations of progesterone (Schmitt et al., 1996a; Santos et al., 2001; Stevenson et al., 2007) through luteotropic effects on the existing CL or by increasing the incidence of ovulation and accessory CL formation (Rajamahendran and Sianangama, 1992; Santos et al., 2001; Stevenson et al., 2007). In addition, luteal phase treatment with hCG after AI has increased conception rates in beef heifers (Breuel et al., 1989) and lactating dairy cows (Santos et al., 2001; Stevenson et al., 2007). In the latter most extensive study (Stevenson et al., 2007) of more than 1,500 cows, no positive effect of hCG in first-service cows was detected, but only in repeat-service cows and second-lactation cows when hCG was administered after AI.

Inducing accessory CL with GnRH or its agonists is well documented and forms the basis for the first $\mathrm{GnRH}$ injection of the Ovsynch protocol (Pursley et al., 1998). Subsequent work demonstrated that incidence of ovulation was greatest when GnRH was injected between d 5 and 12 of the estrous cycle (Vasconcelos et al., 1999). When injected on $\mathrm{d} 5$ or 6 , a $\mathrm{GnRH}$ agonist $(8 \mu \mathrm{g}$ of buserelin) was equally effective as 3,000 IU of hCG for inducing accessory CL, but the subsequent increase in concentrations of progesterone were greater in hCGtreated heifers (Schmitt et al., 1996a).

Lifespan or stayability of induced luteal structures is not known. We demonstrated that 1,000 IU of hCG induced accessory luteal structures in $50 \%$ of pregnant lactating cows between d 26 and 71 of pregnancy (Stevenson et al., 2008). Cows with new luteal structures had greater serum concentrations of progesterone at 1 and 2 wk after treatment than those without induced luteal structures, but approximately one-third of the new luteal structures regressed sometime during the 4-wk post-hCG study period. The majority of those disappearing luteal structures were gone by 2 wk after their induction, and regression occurred more often on the left ovary and contralateral to the CL of pregnancy.

We hypothesized that hCG would increase the number of post-AI luteal structures and progesterone concentration, thereby reducing embryonic loss between AI and the first diagnosis of pregnancy. The objective of the present study was to determine characteristics of luteal structures formed in response to hCG administered on d 7 after AI (first service); specifically, we wanted to find the frequency and characteristics of hCG-induced structures, including size, number, and stayability. Furthermore, we wished to determine whether duration of the estrous cycle or returns to estrus after AI were altered by hCG treatment as well as whether hCG improved pregnancy rate by increasing embryo survival between hCG treatment and d 32 after AI when pregnancy was first diagnosed.

\section{MATERIALS AND METHODS}

\section{Experimental Approach}

Lactating Holstein cows $(\mathrm{n}=328)$ that previously received a timed AI (estrous cycles were presynchronized followed in $10 \mathrm{~d}$ by the Ovsynch protocol; Stevenson et al., 2012) at first service between 61 and 73 DIM were sorted by lactation number ( 1 vs. $\geq 2$ ) and assigned to a completely randomized design consisting of 2 treatments (Figure 1; 164 cows per treatment) when at least 1 CL (visible cavity) was detected on d 7 after AI. More than $96 \%$ of the cows ovulated after the second $\mathrm{GnRH}$ injection of Ovsynch before first AI (Stevenson et al., 2012).

Treatment consisted of 1,000 IU of hCG $(1 \mathrm{~mL}$ of Chorulon; Intervet Schering Plough Animal Health, Millsboro, DE) or $1 \mathrm{~mL}$ of physiological saline administered i.m. In this report, new or induced luteal tissue is referred to as luteal structure(s), rather than CL, because we have no evidence that ovulation (release of ovum) actually occurred even though ultrasonic appearance of these structures resembled other spontaneously formed or GnRH-induced CL.

The current studies were approved by the Kansas State University Institutional Animal Care and Use Committee. Cows were housed in covered freestalls and fed twice or three times (summer) daily a TMR calculated to meet nutrient requirements for lactating dairy cows producing $50 \mathrm{~kg}$ of $3.5 \%$ milk (NRC, 2001). The diet consisted of alfalfa hay, corn silage, soybean meal, whole cottonseed, corn or milo grain, corn gluten feed, vitamins, and minerals. Cows were milked every $8 \mathrm{~h}$ in a double 6 Herringbone milking parlor. 


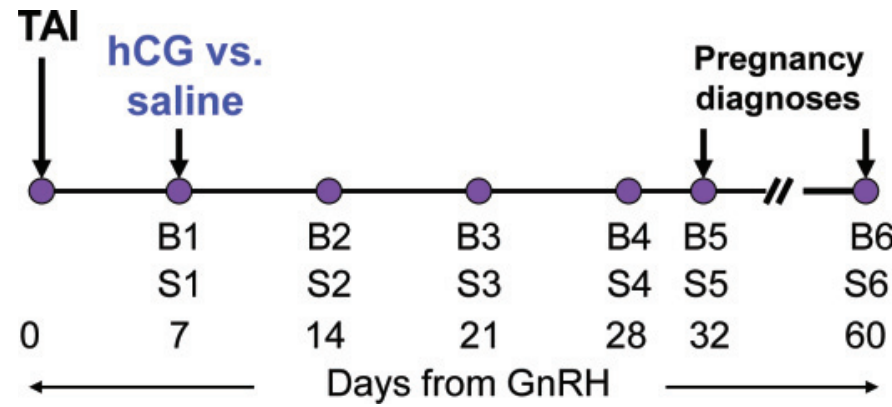

Figure 1. Experimental design of treatments and measurements in lactating dairy cows $(\mathrm{n}=328)$ previously receiving a timed AI (TAI) at first service (estrous cycles were presynchronized followed in $10 \mathrm{~d}$ by the Ovsynch protocol; Stevenson et al., 2012) and treated i.m. with either $1 \mathrm{~mL}$ of saline or 1,000 IU of human chorionic gonadotropin (hCG) on d 7 after AI. Blood (B) samples were collected and ovarian scans (S) were carried out on d 7, 14, 21, 28, and 60. Cows were diagnosed pregnant on d 32 and reconfirmed on d 60. Color version available in the online PDF.

\section{Ovarian Structures and Ovulation}

Ovarian scans were conducted by transrectal ultrasonography $(7.5 \mathrm{mHz}$ transrectal probe, Aloka 500V; Corimetrics, Wallingford, CT) on d 7, 14, 21, 28, and 60 after AI (Figure 1) to measure and map the location of each luteal structure (and each ovarian follicle $>5 \mathrm{~mm}$ in diameter on $\mathrm{d} 7$ only). The volume of each structure was calculated $\left[4 / 3 \times \mathrm{r}^{3} \times \pi\right.$, where $\mathrm{W}=$ largest width and $\mathrm{H}=$ largest height of the structure; $\mathrm{r}=\operatorname{radius}(\mathrm{W} / 2+\mathrm{H} / 2) / 2$, and $\pi=3.14159]$. When a luteal structure contained a fluid-filled cavity, the volume of the cavity was subtracted from the total volume. Pregnancy was diagnosed on d 32 and 60 after AI. A positive pregnancy outcome required the presence of anechoic uterine fluid and a large CL or anechoic uterine fluid and the presence of a viable embryo.

\section{Blood Collection}

Blood samples were collected by caudal vessel venipuncture into evacuated tubes as indicated in Figure 1 on $\mathrm{d} 7,14,21,28,32$, and 60 (pregnant cows only) before each ovarian examination. Concentrations of progesterone in blood serum were measured in all samples by direct quantitative (nonextracted) RIA using Coat-A-Count progesterone kits (catalog \#TKPG; Siemens Medical Solutions Diagnostics, Los Angeles, CA) previously validated for bovine serum (Stevenson et al., 2012). Assay sensitivity was $4.8 \pm 0.5 \mathrm{pg} / \mathrm{mL}$. Inter- and intra-assay coefficients of variation for 14 assays were 5.0 and $4.7 \%$, respectively, for a pooled serum sample that averaged $2.92 \pm 0.02 \mathrm{ng} / \mathrm{mL}(\mathrm{n}=56)$.
In our effort to explain the various pregnancy outcomes described in the results, we used blood samples collected on d 21, 28, 32, and 60 to measure the presence of pregnancy-specific protein B (PSPB; Sasser et al., 1989) to determine if a viable pregnancy existed. Two control levels (high and low) of PSPB were added to all plates in triplicate to allow for determination of inter- and intra-assay precision for each control concentration. Intra-assay precision for each triplicate control concentration was determined by dividing the variation of the 3 measurements on a single plate by the mean of the measurements and multiplying by 100 to give a percentage coefficient of variation. Intra-assay precision for 18 separate assays was 3.6 and $2.5 \%$ for high and low control samples, respectively. Inter-assay precision was 10.3 and $6.8 \%$, respectively, for high and low control samples.

\section{Measurements and Statistical Analyses}

As outlined hereafter, comparisons between treatments (hCG vs. saline) for all continuous dependent variables of interest were made by standard ANOVA procedures (procedure GLM or procedure MIXED; SAS Institute Inc., Cary, NC) or for binomial outcome variables by logistic regression (procedure LOGISTIC; SAS Institute Inc.). Further comparisons among 3 groups of cows were made based on ultrasonographic observations of luteal structures after AI. Two groups of cows detected as not pregnant by ultrasound on d 28 or 32 after AI either had normal regression of all luteal structures by d 28 after AI (not pregnant-no CL; n = 138) or retained some or all of their structures (original, induced by hCG, or both; not pregnant-retained CL; n $=47$ ) to at least $\mathrm{d} 28$. The third group of cows were those detected to be pregnant on d 28 or 32 , which retained their original CL, induced luteal structures, or both (pregnant-retained CL; $\mathrm{n}=143$ ).

Formation of new luteal structures in response to hCG was categorized according to the pretreatment luteal status in which cows had either 1 or 2 or more CL. Luteal responses between treatments within pregnancy status were compared by chi-squared test for cows that had 1 original CL plus either 1 or 2 or more new luteal structures and for cows that had 2 or more original CL plus either 1 or 2 or more new luteal structures after treatment (detected $7 \mathrm{~d}$ after treatment with hCG or saline). A logistic model to assess incidence of new luteal structures included treatment, luteal combinations (original:new; $1: 1,1: \geq 2, \geq 2: 1$, and $\geq 2: \geq 2$ ), and their interactions. Further modeling included total luteal structures on d 7 before treatment (hCG vs. saline), 
total luteal volume on $\mathrm{d} 7$ (median volume: $\leq 5.75$ vs. $>5.75 \mathrm{~cm}^{3}$ ), lactation number (1 vs. $\geq 2$ lactation number), number of luteal structures ( 1 vs. $\geq 2$ ), season [moderate-cold (October through May) vs. hot (June through September) months], test-day ECM nearest the day of AI (median: $\leq 46$ vs. $>46 \mathrm{~kg}$ ), BCS (median: $\leq 2.25$ vs. $>2.25$ ), and DIM (covariable). Adjusted odds ratios and $95 \%$ confidence intervals are reported.

Pregnancy outcomes for various luteal combinations of original CL ( 1 and $\geq 2)$ and induced luteal structures $(0,1$, or $\geq 2)$ were analyzed by chi-squared test. Overall pregnancy per AI determined at d 32 after AI was analyzed by logistic regression. The model included the fixed effects of treatment, lactation number, total luteal volume (median volume: $\leq 10$ vs. $>10 \mathrm{~cm}^{3}$ ) on $\mathrm{d}$ 14 after $\mathrm{AI}$ ( $7 \mathrm{~d}$ after treatment), serum progesterone on d 14 (median: $\leq 6.5$ vs. $>6.5 \mathrm{ng} / \mathrm{mL}$ ), season, BCS, test-day ECM, and DIM (covariable).

Days to reinsemination after first AI were categorized into 3 intervals: $<18,18$ to 25 , and $>25$ d. Proportions of cows in each reinsemination interval were compared between treatments by chi-squared test. Proportions of retained luteal structures (at least 1) were assessed on d 14, 21, 28, and 60 for cows treated with hCG or saline within pregnancy status. Comparisons among treatment-pregnancy status combinations were analyzed by chi-squared test.

Forty cows either gained (+; incidence of new luteal structure that appeared more than $7 \mathrm{~d}$ after treatment) or lost (-; incidence of premature luteal structure regression) a luteal structure(s). Four categories were created: induced $\mathrm{CL}+$ (gained a new $\mathrm{CL} ; \mathrm{n}=8$ ); induced CL- (lost induced CL; $\mathrm{n}=14$ ); original CL- (lost an original $\mathrm{CL} ; \mathrm{n}=15$ ); or induced-/original- (lost induced and original $\mathrm{CL}, \mathrm{n}=3$ ). Comparisons among treatment-pregnancy status combinations were analyzed by chi-squared test.

A mixed model procedure (procedure MIXED; SAS Institute Inc.) was used to analyze repeat measures assessed on $\mathrm{d} 7,14,21,28$, and 60. These included progesterone and PSPB concentrations, number of CL, original CL volume, induced luteal structure volume, and total luteal volume. Treatment, pregnancy status, and day were included in the model. For some models, the 3 groups of cows with differing luteal status (described previously as not pregnant-no CL, not pregnant-retained CL, or pregnant-retained CL) replaced treatment in the model. Least squares means comparisons were made by least significant differences in cases where more than 2 means were generated; otherwise, comparisons between treatments were by F-tests resulting from ANOVA.

\section{RESULTS}

\section{New Luteal Structures After hCG Administration}

Overall formation of new luteal structures in response to hCG was $70 \%$ (Table 1). We also observed some spontaneously newly formed luteal structures in cows receiving saline treatment $(2.4 \%)$. As expected, more $(P$ $<0.001)$ new luteal structures were formed after hCG than after saline. Frequency of forming 1 new luteal structure after hCG when 1 pretreatment CL existed $(51.7 \%)$ did not differ from that for cows having 2 or more pretreatment CL $(56.2 \%)$, but in both categories of original CL ( 1 vs. $\geq 2$ ), the frequencies of forming $\geq 2$ new luteal structures when $\geq 2$ original CL already existed was less $(P<0.05 ; 17.2<51.7 \%$ and $16.7<$ $56.2 \%$; Table 1), respectively. Differential responses to hCG in cows with 1 or 2 or more pretreatment CL were related to the endogenous pretreatment progesterone concentration. Cows with only 1 pretreatment CL had lesser $(P<0.001)$ concentrations of progesterone than those with 2 or more CL $(2.3 \pm 0.1$ vs. $3.8 \pm 0.1 \mathrm{ng} /$ $\mathrm{mL}$ ). Formation of new luteal structures was $65.3 \%$ in nonpregnant cows and $74.2 \%$ in pregnant cows (Table $1)$.

Among other factors, including pretreatment CL volume, progesterone concentration, number of CL, lactation number, season, DIM, BCS, and ECM, only ECM influenced the response to treatment. Cows producing more than the median of $46 \mathrm{~kg}$ of ECM per day were less $(P=0.014)$ likely (odds ratio $=0.44 ; \mathrm{CI}=0.23$ to $0.85)$ to form new luteal structures than cows producing $<46 \mathrm{~kg}$ of ECM.

Progesterone concentrations in blood serum differed between hCG and saline cows (Figure 2; upper panel). Concentrations began to diverge on or after $\mathrm{d} 14(7 \mathrm{~d}$ after treatment) and remained different $(P<0.001)$ until d 28 for all cows and for pregnant hCG-treated cows on $\mathrm{d} 32$ and 60 .

Patterns of progesterone according to pregnancy status and whether new luteal structures were formed in response to hCG are illustrated (Figure 2; lower panel). Among nonpregnant cows on d 14, progesterone concentrations in saline and $\mathrm{hCG}-$ (no response to hCG) cows did not differ, but were less $(P<0.01)$ than concentrations in hCG+ (response to hCG) cows. Furthermore, pregnant-hCG - cows on d 14 did not differ from the nonpregnant-saline and nonpregnant-hCGcows, indicating that hCG did not induce greater progesterone secretion in cows that failed to ovulate but whose original CL was (or were) exposed to hCG. For pregnant cows on d 14, progesterone concentrations in 
Table 1. Appearance of new luteal structures [\% new structures (n)] in response to human chorionic gonadotropin (hCG) administered on $\mathrm{d} 7$ after AI according to pretreatment luteal and pregnancy status

\begin{tabular}{lcccc}
\hline Item & $\begin{array}{c}\text { New luteal } \\
\text { structure }^{2}\end{array}$ & Nonpregnant & Pregnant & $\Sigma$ \\
\hline Original CL & & & & \\
1 & 0 & $0.0(26)$ & $0.0(10)$ & $0.0(36)$ \\
1 & 1 & $42.0(29)$ & $66.0(31)$ & $51.7^{\mathrm{a}}(60)$ \\
1 & $\geq 2$ & $20.3(14)$ & $12.8(6)$ & $17.2^{\mathrm{b}}(20)$ \\
1 CL subtotal & 3 (\%) & $62.3(69)$ & $78.8(47)$ & $68.9(116)$ \\
$\geq 2$ & 0 & $0.0(8)$ & $0.0(5)$ & $0.0(13)$ \\
$\geq 2$ & 1 & $58.6(17)$ & $52.6(10)$ & $56.2^{\mathrm{a}}(27)$ \\
$\geq 2$ & $\geq 2$ & $13.8(4)$ & $21.1(4)$ & $16.7^{\mathrm{b}}(8)$ \\
Total new structures $^{5}(\%)$ & & $72.4(29)$ & $73.7(19)$ & $72.9(48)$ \\
& & $65.3(98)$ & $74.2(66)$ & $70.0(164)$ \\
\hline
\end{tabular}

$\overline{\mathrm{a}, \mathrm{b}}$ Within original corpus luteum $(\mathrm{CL})$ category, percentages with different superscript letters differ $(P<0.05)$.

${ }^{1}$ Number of pretreatment CL on d 7 after AI.

${ }^{2}$ Number of new luteal structures on d 14 in response to treatment $7 \mathrm{~d}$ earlier.

${ }^{3}$ Proportion of cows with 1 original CL that had either 0,1 , or 2 or more $(\geq 2)$ new luteal structure(s) detected on $\mathrm{d} 14$ ( $7 \mathrm{~d}$ after treatment).

${ }^{4}$ Proportion of cows with $\geq 2$ original CL that had 0,1 , or 2 or more $(\geq 2)$ new luteal structure(s) detected on d 14 ( 7 d after treatment).

${ }^{5}$ Overall frequency of new luteal structures.
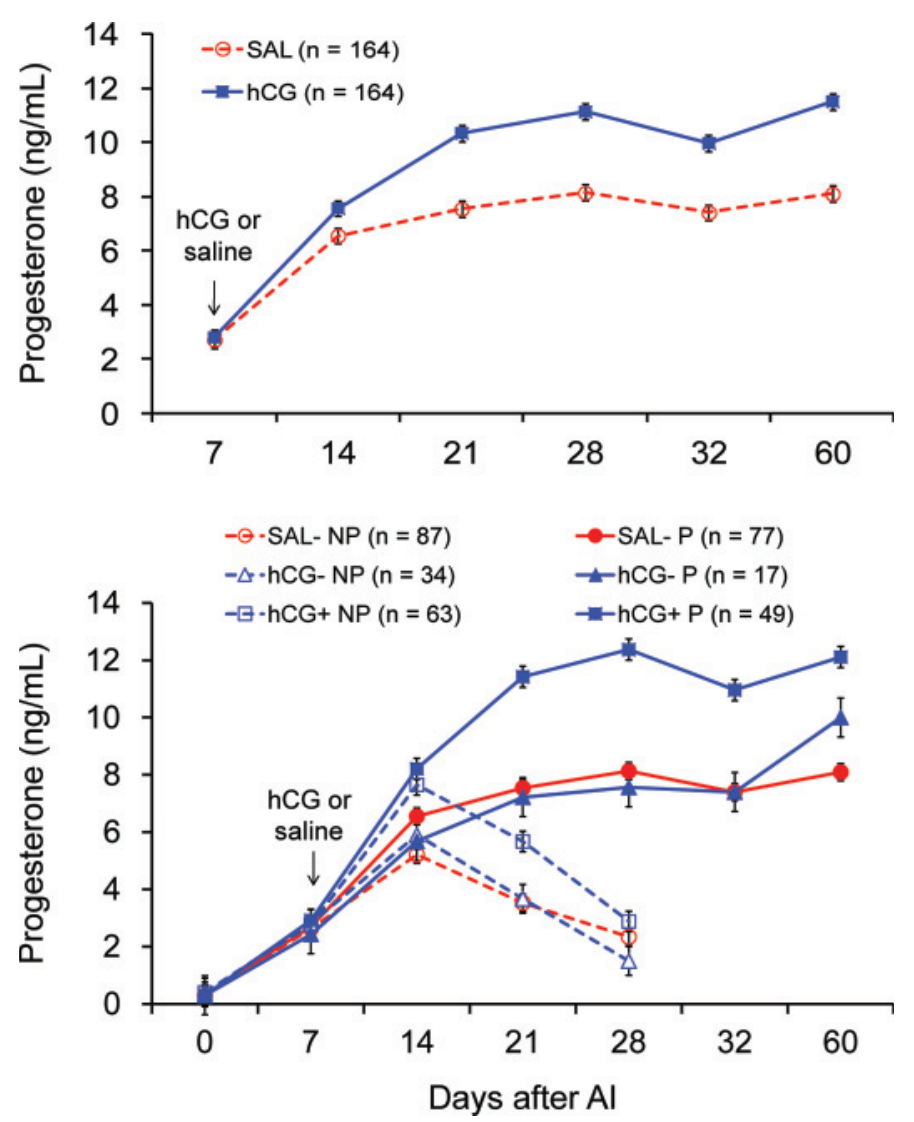

Figure 2. Concentrations of progesterone after timed AI and in response to human chorionic gonadotropin (hCG) or saline (SAL) treatment on $\mathrm{d} 7$ after AI (top panel) according to pregnant (P) or nonpregnant (NP) status on d 32 after AI, and positive (+; new luteal structure) or negative (-) response to hCG on d 7 after AI (bottom panel). Error bars represent least squares means \pm standard error. Color version available in the online PDF. saline and $\mathrm{hCG}-$ (no response to $\mathrm{hCG}$ ) cows did not differ, but were less $(P<0.01)$ than concentrations in hCG+ (response to hCG) cows. This same pattern persisted, but was more exaggerated on d 21 and 28 after AI as luteolysis occurred. Among pregnant cows on or after d 21, progesterone was greater $(P<0.01)$ in $\mathrm{hCG}+$ cows than in $\mathrm{hCG}-$ and saline cows.

\section{Luteal Structure Characteristics}

The mean number of luteal structures was greater $(P$ $<0.001)$ in hCG-treated cows that formed new luteal structures regardless of pregnancy status compared with hCG-treated cows that did not respond or in saline cows (Table 2). This difference persisted until d 60 .

The original volume of pretreatment-formed CL (Table 2), monitored until d 60, followed the same pattern as the mean number of CL. On d 14, however, the original CL volume was greater $(P<0.05)$ in pregnant$\mathrm{hCG}+$ cows than in all other groups. In contrast to a lack of increase in progesterone among nonpregnant cows treated with hCG that failed to form new luteal structures, the volume of the original CL in these cows was larger than that in nonpregnant-saline cows, indicating that original $\mathrm{CL}$ exposed to $\mathrm{hCG}$ was altered by hCG treatment. The smallest original CL volumes on d 14 were detected in nonpregnant-saline and pregnant-hCG- cows. By d 21, as a result of luteolysis, nonpregnant cows had lesser $(P<0.05)$ original CL volumes than pregnant cows except for the pregnanthCG- cows. This pattern persisted to d 28. By d 60, all pretreatment-formed CL in pregnant cows had similar volumes regardless of treatment. 
Table 2. Luteal characteristics in lactating dairy cows on d 7, 14, 21, 28, and 60 after AI in response to human chorionic gonadotropin (hCG) treatment on d 7 after AI (values are $\mathrm{LSM} \pm \mathrm{SE}$, with no. of cows in parentheses)

\begin{tabular}{|c|c|c|c|c|c|c|c|}
\hline \multirow[b]{3}{*}{ Item } & \multirow[b]{3}{*}{ Day } & \multicolumn{6}{|c|}{ Treatment $^{1}$} \\
\hline & & \multicolumn{3}{|c|}{ Not pregnant } & \multicolumn{3}{|c|}{ Pregnant } \\
\hline & & Saline & $\mathrm{hCG}^{-}$ & hCG+ & Saline & $\mathrm{hCG}^{-}$ & $\mathrm{hCG}+$ \\
\hline Luteal structures per cow (no.) & $\begin{array}{r}7 \\
14 \\
21 \\
28 \\
60\end{array}$ & $\begin{array}{c}1.3 \pm 0.03^{\mathrm{a}}(87) \\
1.3 \pm 0.03^{\mathrm{a}}(85) \\
1.0 \pm 0.03^{\mathrm{a}}(73) \\
1.3 \pm 0.06^{\mathrm{a}}(22) \\
-\end{array}$ & $\begin{array}{c}1.3 \pm 0.03^{\mathrm{a}}(34) \\
1.3 \pm 0.03^{\mathrm{a}}(34) \\
1.3 \pm 0.03^{\mathrm{a}}(27) \\
1.2 \pm 0.03^{\mathrm{a}}(7) \\
-\end{array}$ & \begin{tabular}{l}
$1.3 \pm 0.03^{\mathrm{a}}(64)$ \\
$2.6 \pm 0.03^{\mathrm{b}}(64)$ \\
$2.5 \pm 0.03^{\mathrm{b}}(56)$ \\
$2.5 \pm 0.06^{\mathrm{b}}(18)$ \\
\multicolumn{2}{c}{}
\end{tabular} & $\begin{array}{l}1.2 \pm 0.03^{\mathrm{a}}(77) \\
1.2 \pm 0.03^{\mathrm{a}}(77) \\
1.2 \pm 0.03^{\mathrm{a}}(77) \\
1.2 \pm 0.03^{\mathrm{a}}(77) \\
1.2 \pm 0.08^{\mathrm{a}}(60)\end{array}$ & $\begin{array}{l}1.4 \pm 0.06^{\mathrm{a}}(15) \\
1.3 \pm 0.06^{\mathrm{a}}(15) \\
1.3 \pm 0.06^{\mathrm{a}}(15) \\
1.3 \pm 0.06^{\mathrm{a}}(15) \\
1.3 \pm 0.2^{\mathrm{a}}(11)\end{array}$ & $\begin{array}{l}1.3 \pm 0.03^{\mathrm{a}}(51) \\
2.5 \pm 0.03^{\mathrm{b}}(51) \\
2.5 \pm 0.03^{\mathrm{b}}(51) \\
2.5 \pm 0.03^{\mathrm{b}}(51) \\
2.2 \pm 0.09^{\mathrm{b}}(43)\end{array}$ \\
\hline Original CL volume ${ }^{1}\left(\mathrm{~cm}^{3}\right)$ & $\begin{array}{r}7 \\
14 \\
21 \\
28 \\
60\end{array}$ & $\begin{array}{c}6.0 \pm 0.4^{\mathrm{a}}(87) \\
7.5 \pm 0.4^{\mathrm{a}}(85) \\
5.6 \pm 0.4^{\mathrm{a}}(73) \\
4.0 \pm 0.6^{\mathrm{a}}(22) \\
-\end{array}$ & $\begin{array}{l}6.4 \pm 0.6^{\mathrm{a}}(34) \\
9.2 \pm 0.6^{\mathrm{bc}}(34) \\
6.6 \pm 0.6^{\mathrm{a}}(27) \\
5.2 \pm 1.1^{\mathrm{a}}(7) \\
-\end{array}$ & $\begin{array}{c}6.5 \pm 0.4^{\mathrm{a}}(64) \\
9.1 \pm 0.4^{\mathrm{b}}(64) \\
6.1 \pm 0.4^{\mathrm{a}}(56) \\
5.5 \pm 0.7^{\mathrm{a}}(18) \\
-\end{array}$ & $\begin{array}{l}6.4 \pm 0.4^{\mathrm{a}}(77) \\
8.8 \pm 0.4^{\mathrm{b}}(77) \\
8.0 \pm 0.4^{\mathrm{b}}(77) \\
8.2 \pm 0.4^{\mathrm{b}}(77) \\
9.0 \pm 0.4^{\mathrm{a}}(60)\end{array}$ & $\begin{array}{l}5.5 \pm 0.9^{\mathrm{a}}(15) \\
7.8 \pm 0.9^{\mathrm{a}}(15) \\
6.9 \pm 0.9^{\mathrm{ab}}(15) \\
5.8 \pm 0.9^{\mathrm{a}}(15) \\
8.4 \pm 0.8^{\mathrm{a}}(11)\end{array}$ & $\begin{aligned} 6.5 & \pm 0.5^{\mathrm{a}}(51) \\
10.5 & \pm 0.5^{\mathrm{c}}(51) \\
8.0 & \pm 0.5^{\mathrm{b}}(51) \\
7.3 \pm 0.5^{\mathrm{b}}(51) & \\
8.4 & \pm 0.4^{\mathrm{a}}(43)\end{aligned}$ \\
\hline Induced luteal volume ${ }^{2}\left(\mathrm{~cm}^{3}\right)$ & $\begin{array}{r}7 \\
14 \\
21 \\
28 \\
60\end{array}$ & $\begin{array}{c}-\overline{-} \\
1.2 \pm 2.6^{\mathrm{a}}(1) \\
1.2 \pm 2.6^{\mathrm{a}}(1) \\
- \\
-\end{array}$ & $\begin{array}{l}- \\
- \\
-\end{array}$ & $\begin{array}{c}- \\
4.9 \pm 0.3^{\mathrm{a}}(64) \\
4.8 \pm 0.3^{\mathrm{a}}(52) \\
3.2 \pm 0.6^{\mathrm{a}}(16) \\
-\end{array}$ & $\begin{array}{l}9.0 \pm 1.8^{\mathrm{b}}(2) \\
4.9 \pm 1.8^{\mathrm{ab}}(2) \\
2.4 \pm 1.8^{\mathrm{ab}}(2) \\
4.8 \pm 2.4^{\mathrm{a}}(60)\end{array}$ & $\begin{array}{l}- \\
- \\
-\end{array}$ & $\begin{array}{l}5.1 \pm 0.4^{\mathrm{a}}(51) \\
6.0 \pm 0.4^{\mathrm{b}}(51) \\
5.8 \pm 0.4^{\mathrm{b}}(51) \\
6.4 \pm 0.6^{\mathrm{a}}(43)\end{array}$ \\
\hline Total luteal volume ${ }^{3}\left(\mathrm{~cm}^{3}\right)$ & $\begin{array}{r}7 \\
14 \\
21 \\
28 \\
60\end{array}$ & $\begin{array}{c}6.0 \pm 0.4^{\mathrm{a}}(86) \\
7.5 \pm 0.4^{\mathrm{a}}(84) \\
5.6 \pm 0.4^{\mathrm{a}}(72) \\
4.0 \pm 0.7^{\mathrm{a}}(21) \\
-\end{array}$ & \begin{tabular}{c}
$6.4 \pm 0.6^{\mathrm{a}}(97)$ \\
$9.2 \pm 0.6^{\mathrm{b}}(97)$ \\
$6.5 \pm 0.7^{\mathrm{a}}(82)$ \\
$5.1 \pm 1.2^{\mathrm{a}}(24)$ \\
\multicolumn{2}{c}{}
\end{tabular} & $\begin{array}{r}6.5 \pm 0.5^{\mathrm{a}}(97) \\
14.0 \pm 0.5^{\mathrm{c}}(97) \\
10.7 \pm 0.5^{\mathrm{b}}(82) \\
8.2 \pm 0.8^{\mathrm{b}}(24) \\
\end{array}$ & $\begin{array}{l}6.4 \pm 0.4^{\mathrm{a}}(78) \\
9.0 \pm 0.4^{\mathrm{b}}(78) \\
8.2 \pm 0.4^{\mathrm{b}}(78) \\
8.3 \pm 0.4^{\mathrm{b}}(78) \\
9.2 \pm 0.5^{\mathrm{a}}(60)\end{array}$ & $\begin{array}{l}-\overline{-}^{\mathrm{ab}}(67) \\
6.8 \pm 1.0^{\mathrm{a}}\left(670^{\mathrm{a}}(67)\right. \\
5.8 \pm 1.0^{\mathrm{a}}(67) \\
8.4 \pm 1.1^{\mathrm{a}}(54)\end{array}$ & $\begin{array}{r}6.5 \pm 0.5^{\mathrm{a}}(67) \\
15.6 \pm 0.5^{\mathrm{c}}(67) \\
14.0 \pm 0.5^{\mathrm{c}}(67) \\
12.9 \pm 0.5^{\mathrm{c}}(67) \\
13.4 \pm 0.6^{\mathrm{b}}(54)\end{array}$ \\
\hline
\end{tabular}

${ }^{\mathrm{a}-\mathrm{C}}$ Means within a row having different superscript letters differ $(P \leq 0.05)$.

욜 ${ }^{1}$ Volume of all original corpora lutea (CL).

$\stackrel{2}{\equiv}$ Volume of all new luteal structures in response to treatment.

ஸ) ${ }^{3}$ Total volume of all luteal structures (original plus induced). 
The volume of induced luteal structures was greater $(P<0.05)$ in hCG than saline cows on d 14 (Table 2$)$. On d 21 and 28, hCG cows had greater induced luteal volume than saline cows, but volume in nonpregnanthCG-treated cows was intermediate in magnitude and differed $(P<0.05)$ from saline and pregnant-hCG cows. The induced luteal structure volume in pregnant cows on d 60 remained greater $(P<0.05)$ in those treated with hCG than with saline.

The total luteal volume (original CL plus induced luteal structures) between nonpregnant-hCG- and pregnant-hCG + cows did not differ on d 14, but both were greater $(P<0.05)$ than the remaining 4 groups (Table 2). Patterns were similar for d 21, but volume in the nonpregnant-hCG- cows decreased and differed $(P<0.05)$ from the pregnant-hCG+ cows and all remaining groups. Patterns were similar on $\mathrm{d} 28$, but the volume in pregnant-saline cows was also intermediate in volume. By d 60 of pregnancy, hCG + cows had greater $(P<0.05)$ luteal volume than that detected in $\mathrm{hCG}-$ and saline cows.

\section{Pregnancy Outcomes}

Pregnancy per AI on d 32 and 60 is summarized according to treatment and pre- and posttreatment luteal status (Table 3). Pregnancy per AI on d 32 and 60 was less $(P<0.05)$ in hCG than saline cows. This difference occurred because hCG-treated cows bearing 1 , but not 2 , original CL, which failed to respond to $\mathrm{hCG}$, had reduced $(P<0.05)$ pregnancy per AI, ranging from 55 to $61 \%$ of that observed in saline cows. In all other com- binations of original pretreatment CL and new luteal structures, pregnancy per $\mathrm{AI}$ in hCG cows was equal to or greater than that of saline cows.

In addition to treatment, factors that significantly influenced pregnancy rate included progesterone concentration $7 \mathrm{~d}$ after treatment and season of the year (Table 4). Cows with progesterone concentration $>6.5 \mathrm{ng} / \mathrm{mL}$ were 1.84 times more $(P=0.021)$ likely to conceive than cows with progesterone $\leq 6.5 \mathrm{ng} / \mathrm{mL}$. As expected, cows inseminated and treated with hCG during hot months were less $(P<0.001)$ likely to conceive than cows during cooler months. Neither lactation number, total luteal volume on d 14, ECM, nor BCS significantly influenced pregnancy outcome.

\section{Return to Service}

Treatment with hCG reduced $(P<0.05)$ by half the proportion of cows reinseminated between 18 and $25 \mathrm{~d}$ after first AI (Table 5). As a result, more $(P<0.05)$ hCG cows were reinseminated after d 25 . For cows with $>25 \mathrm{~d}$ to reinsemination, concentrations of progesterone were greater $(P<0.001)$ in hCG- than saline-treated cows on $\mathrm{d} 14(7.1 \pm 0.3$ vs. $5.2 \pm 0.3 \mathrm{ng} / \mathrm{mL})$ and $\mathrm{d}$ $21(5.2 \pm 0.3$ vs. $3.9 \pm 0.3 \mathrm{ng} / \mathrm{mL})$, respectively, but concentrations were similar $(2.5 \pm 0.4 \mathrm{ng} / \mathrm{mL})$ between treatments by d 28 .

\section{Retention or Loss of Luteal Structures}

Retention of at least 1 post-AI luteal structure in cows treated with hCG or saline through d 28 in non-

Table 3. Pregnancy per AI on d 32 and 60 after AI according to pre- and post-human chorionic gonadotropin (hCG) treatment luteal status on d 7 after AI

\begin{tabular}{|c|c|c|c|c|c|}
\hline \multirow[b]{3}{*}{ Item } & \multirow{3}{*}{$\begin{array}{l}\text { New luteal } \\
\text { structure }^{2}\end{array}$} & \multicolumn{4}{|c|}{ Treatment $^{3}$} \\
\hline & & \multicolumn{2}{|c|}{ d $32[\%(n)]$} & \multicolumn{2}{|c|}{ d $60[\%(n)]$} \\
\hline & & $\mathrm{hCG}$ & Saline & hCG & Saline \\
\hline \multicolumn{6}{|c|}{ Original $\mathrm{CL}^{1}$} \\
\hline 1 & 0 & $27.8(36)$ & $50.0(120)$ & $25.7(35)$ & $42.0(119)$ \\
\hline 1 & 1 & $51.7(60)$ & $33.3(3)$ & $45.8(59)$ & $33.3(3)$ \\
\hline 1 & $\geq 2$ & $30.0(20)$ & $0.0(0)$ & $25.0(20)$ & $0.0(0)$ \\
\hline 1 & & $40.5^{\mathrm{a}}(116)$ & $49.6^{\mathrm{b}}(123)$ & $36.0^{\mathrm{a}}(114)$ & $41.8^{\mathrm{a}}(122)$ \\
\hline$\geq 2$ & 0 & $38.5(13)$ & $37.5(40)$ & $50.0(6)$ & $35.9(39)$ \\
\hline$\geq 2$ & 1 & $37.0(27)$ & $100(1)$ & $34.6(26)$ & $0.0(1)$ \\
\hline$\geq 2$ & $\geq 2$ & $50.0(8)$ & $0.0(0)$ & $42.9(7)$ & $0.0(0)$ \\
\hline$\overline{\geq} 2$ & & $39.6^{\mathrm{a}}(48)$ & $39.0^{\mathrm{a}}(41)$ & $33.3^{\mathrm{a}}(39)$ & $25.0^{\mathrm{a}}(40)$ \\
\hline Overa & per $\mathrm{AI}^{4}$ & $40.2^{\mathrm{a}}(164)$ & $47.0^{\mathrm{b}}(164)$ & $35.2^{\mathrm{a}}(159)$ & $40.1^{\mathrm{b}}(162)$ \\
\hline \multicolumn{6}{|c|}{$\begin{array}{l}\overline{a, b} \text { Means within day of pregnancy diagnosis with different superscript letters differ between treatments }(P \\
0.05) \text {. }\end{array}$} \\
\hline \multicolumn{6}{|c|}{${ }^{1}$ Number of corpora lutea (CL) before treatment on d 7 after AI. } \\
\hline \multicolumn{6}{|c|}{${ }^{2}$ Number of new luteal structures detected $7 \mathrm{~d}$ after treatment in response to $\mathrm{hCG}$. } \\
\hline \multicolumn{6}{|c|}{${ }^{3}$ Cows were treated with either hCG or saline on d 7 after AI. } \\
\hline \multicolumn{6}{|c|}{${ }^{4}$ Seven cows were culled before d 60 pregnancy status was determined. } \\
\hline
\end{tabular}


Table 4. Factors affecting pregnancy per AI at d 32 after AI among first-service cows treated with human chorionic gonadotropin (hCG) or saline on d 7 after AI

\begin{tabular}{|c|c|c|c|c|}
\hline Factor & $\%(\mathrm{n})$ & Odds ratio & $95 \% \mathrm{CI}$ & $P$-value \\
\hline \multicolumn{5}{|l|}{ Treatment $^{1}$} \\
\hline $\mathrm{hCG}$ & $40.2(164)$ & & & \\
\hline Saline & $47.5(162)$ & 1.93 & $1.12-3.32$ & 0.017 \\
\hline \multicolumn{5}{|l|}{ Lactation number } \\
\hline 1 & $41.2(136)$ & & & \\
\hline $2+$ & $45.8(190)$ & 1.29 & $0.71-2.33$ & 0.399 \\
\hline \multicolumn{5}{|l|}{ Total luteal volume ${ }^{2}$} \\
\hline$\leq 10 \mathrm{~cm}^{3}$ & $40.6(160)$ & & & \\
\hline$>10 \mathrm{~cm}^{3}$ & $47.0(166)$ & 1.41 & $0.81-2.45$ & 0.230 \\
\hline \multicolumn{5}{|c|}{ Progesterone $^{3}(\mathrm{ng} / \mathrm{mL})$} \\
\hline$\leq 6.5$ & $36.8(163)$ & & & \\
\hline$>6.5$ & $50.9(163)$ & 1.84 & $1.10-3.09$ & 0.021 \\
\hline \multicolumn{5}{|l|}{ Season } \\
\hline Moderate to cold & $52.7(260)$ & & & \\
\hline Hot & $9.1(66)$ & 0.09 & $0.03-0.21$ & 0.001 \\
\hline \multicolumn{5}{|l|}{$\mathrm{ECM}^{4}(\mathrm{~kg})$} \\
\hline$\leq 46$ & $39.5(162)$ & & & \\
\hline$>46$ & $48.2(164)$ & 0.91 & $0.50-1.65$ & 0.745 \\
\hline \multicolumn{5}{|l|}{ BCS } \\
\hline$\leq 2.25$ & $43.3(150)$ & & & \\
\hline$>2.25$ & $44.3(176)$ & 1.03 & $0.62-1.69$ & 0.919 \\
\hline
\end{tabular}

${ }^{1}$ Cows were treated with either hCG or saline on d 7 after AI. Two of the 328 cows had no corpus luteum (CL) on $\mathrm{d} 14$ (premature luteal regression).

${ }^{2}$ Total luteal volume assessed $7 \mathrm{~d}$ after treatment (d 14 after AI).

${ }^{3}$ Concentration assessed $7 \mathrm{~d}$ after treatment (d 14 after AI).

${ }^{4}$ Energy-corrected test-day milk nearest date of treatment.

pregnant cows or through d 60 in pregnant cows is summarized in Table 6 . By d 21, more than $82 \%$ of cows diagnosed as not pregnant on d 32 retained at least 1 original or induced luteal structure. By d 28, this proportion was $25 \%$ and did not differ between treatments.

Among hCG-treated pregnant cows that formed new luteal structures identified $7 \mathrm{~d}$ after hCG treatment (51 of 66 cows), 41 cows had 1 new luteal structure and 10 cows formed 2 luteal structures. None of these induced luteal structures regressed until d 28, when 2.5 and $10 \%$ had regressed, respectively. By d 60 of pregnancy of those cows that remained pregnant, a total of 29.3

Table 5. Proportion of cows reinseminated at various intervals after first insemination

\begin{tabular}{|c|c|c|}
\hline \multirow{3}{*}{$\begin{array}{l}\text { Days to } \\
\text { reinsemination }\end{array}$} & \multicolumn{2}{|c|}{ Treatment $^{1}$} \\
\hline & Saline & hCG \\
\hline & \multicolumn{2}{|c|}{$\%(\mathrm{n} / \mathrm{n})$} \\
\hline $\begin{array}{l}<18 \\
18 \text { to } 25 \\
>25\end{array}$ & $\begin{array}{c}4.8(3 / 63) \\
33.3^{\mathrm{a}}(21 / 63) \\
61.9^{\mathrm{a}}(39 / 63)\end{array}$ & $\begin{array}{c}1.4(1 / 72) \\
15.3^{\mathrm{b}}(11 / 72) \\
83.3^{\mathrm{b}}(60 / 72)\end{array}$ \\
\hline
\end{tabular}

$\overline{\mathrm{a}, \mathrm{b}}$ Means with different superscript letters differ between treatments $(P<0.05)$.

${ }^{1}$ Cows were treated with either human chorionic gonadotropin (hCG) or saline on $\mathrm{d} 7$ after AI. and $50 \%$ of the new luteal structures had regressed, respectively.

Among 98 hCG-treated nonpregnant cows, 45 cows had 1 new luteal structure and 10 cows formed 2 luteal structures after hCG. By d 21 after AI, $20 \%$ of cows with 1 induced structure and $15.8 \%$ of cows with 2 structures had lost these induced structures. By d 28, 71.1 and $84.2 \%$ of these luteal structures had regressed, respectively.

Some oddities occurred in $40(12.2 \%)$ of the 328 cows, of which 28 of the 40 cows were pregnant $(60.7 \%)$. Eight cows had induced luteal structures (inducedgained) that appeared more than $7 \mathrm{~d}$ after treatment; 14 cows had induced luteal structures that regressed prematurely (induced-lost); 15 cows had their original CL regress prematurely but still retained at least 1 functional luteal structure (original-lost); and 3 cows had an induced structure and an original CL regress prematurely but retained at least 1 functional luteal structure (induced-gained/original-lost).

In 7 of the 8 induced-gained luteal structure cows, the late-appearing luteal structure was detected ipsilateral to the original CL. In 11 of the 14 induced-lost luteal structure cows, the prematurely regressed induced luteal structure was contralateral to the original CL. In 8 of the 15 original-lost luteal structure cows, pregnancies persisted to d 60 , but the induced luteal structure 
Table 6. Retention of at least 1 corpus luteum (CL) after pretreatment insemination

\begin{tabular}{|c|c|c|c|c|c|c|}
\hline \multirow[b]{3}{*}{ Treatment $^{1}$} & \multirow{3}{*}{$\begin{array}{l}\text { Pregnancy } \\
\text { status }^{2}\end{array}$} & & \multicolumn{4}{|c|}{ Days from AI } \\
\hline & & \multirow[b]{2}{*}{$\mathrm{n}$} & 14 & 21 & 28 & 60 \\
\hline & & & \multicolumn{4}{|c|}{ Retention $^{3}(\%)$} \\
\hline \multirow[t]{2}{*}{ hCG } & Not pregnant & 98 & 100.0 & 84.7 & 25.5 & - \\
\hline & Pregnant & 66 & 100.0 & 100.0 & 100.0 & 81.8 \\
\hline \multirow[t]{2}{*}{ Saline } & Not pregnant & 87 & 97.7 & 82.8 & 25.3 & - \\
\hline & Pregnant & 77 & 100.0 & 100.0 & 100.0 & 77.9 \\
\hline
\end{tabular}

disappeared between d 28 and 60 of pregnancy. All 15 original-lost luteal structure cows started with more than 2 CL per cow; in 7 of 15 , the disappearing original CL was (or were) gone by d 14 and all 7 cows were later diagnosed as not pregnant; in 6 of the remaining 8 cows, the lost CL disappeared between d 14 and 21, and 5 of the 6 cows were later diagnosed as not pregnant. Of the remaining 2 cows, 1 of the original 2 CL disappeared between d 32 and 60 of pregnancy.

The 3 induced-gained/original-lost luteal structure cows started with 3 original CL per cow but lost original and induced luteal structures. One cow lost 1 original CL and 1 induced luteal structure between d 32 and 60 of pregnancy. The remaining 2 nonpregnant cows lost 1 original CL and 1 induced luteal structure between $\mathrm{d}$ 14 and 21.

\section{Progesterone and PSPB}

We further considered the retention of luteal structures by examining concentrations of progesterone and PSPB in nonpregnant (nonpregnant-retained CL) and pregnant (pregnant-retained CL) cows that retained at least 1 luteal structure to d 28 after AI as well as in cows in which all structures regressed (nonpregnant-no CL) before d 28. Pretreatment concentrations of progesterone on d 7 did not differ among groups before treatment with hCG or saline (Figure 3). On d 14, however, only saline-treated nonpregnant-no CL cows had lesser $(P<0.05)$ concentrations of progesterone, indicating that either hCG, pregnancy status, or both increased progesterone secretion. By d 21, cows that retained their luteal structures and were pregnant or retained their luteal structures and were not pregnant on $\mathrm{d} 28$ or 32 had greater $(P<0.05)$ concentrations of progesterone than cows whose luteal structures regressed before d 28. In addition, on d 21, hCG further increased $(P<0.05)$ progesterone in pregnant cows compared with all other groups. By d 28, the 3 groups of cows differed $(P<0.05)$ from one another within treatment (Figure 3) and pregnant, hCG-treated cows had the largest concentrations compared with all other groups.

Averaged across treatments of hCG and saline, concentrations of progesterone for nonpregnant cows that retained their luteal structures to d 28 were consistently intermediate between the nonpregnant-no CL and the pregnant-retained CL groups except for pretreatment progesterone concentrations on $\mathrm{d} 7$. Concentrations for 138 nonpregnant-no CL cows, 47 nonpregnant-retained CL cows, and 143 pregnant-retained CL cows on d 14 were $5.9 \pm 0.2^{\mathrm{a}}, 6.7 \pm 0.4^{\mathrm{a}, \mathrm{b}}$, and $7.1 \pm 0.2^{\mathrm{b}} \mathrm{ng} / \mathrm{mL} ; \mathrm{d}$ 21: $3.4 \pm 0.2^{\mathrm{a}}, 6.7 \pm 0.4^{\mathrm{b}}$, and $9.0 \pm 0.2^{\mathrm{c}} \mathrm{ng} / \mathrm{mL}$; and d 28: $1.4 \pm 0.2^{\mathrm{a}}, 5.2 \pm 0.4^{\mathrm{b}}$, and $9.6 \pm 0.2^{\mathrm{c}} \mathrm{ng} / \mathrm{mL}$, respectively (superscripts a-c indicate $P<0.01$ ). These progesterone patterns indicated that some cows in the nonpregnant-retained CL group were likely pregnant and suffered embryo loss before a positive pregnancy diagnosis was made by ultrasound on d 28 or 32 .

This potential for pregnancy in the nonpregnantCL retained group that resulted in subsequent early embryonic loss is supported by elevated concentrations of PSPB in cows in the 3 groups. Although concentrations did not differ on d 21, 28, or 32 between the 2 groups with retained CL for which a full complement of samples were available for all 3 sampling days (d 21, 28, and 32), when all samples were included in the analysis, the nonpregnant-no CL group tended $(P=0.08)$ to differ from the nonpregnant-retained CL group (55.4 vs. $134.0 \mathrm{pg} / \mathrm{mL}$ ) on d 32 (Figure 4). Only 6 of 31 cows in the nonpregnant-retained CL group (for which samples for PSPB were available on d 21, 28, and 32) had elevated PSPB $(>100 \mathrm{pg} / \mathrm{mL})$ on d 32. Furthermore, only 2 of these 6 cows had elevated PSPB on both $\mathrm{d} 28$ and 32. A lack of any significant PSPB elevation on d 28 in nonpregnant retained-CL cows may be a dilution effect of the remaining cows having concentrations of PSPB at or near the sensitivity of the assay. 

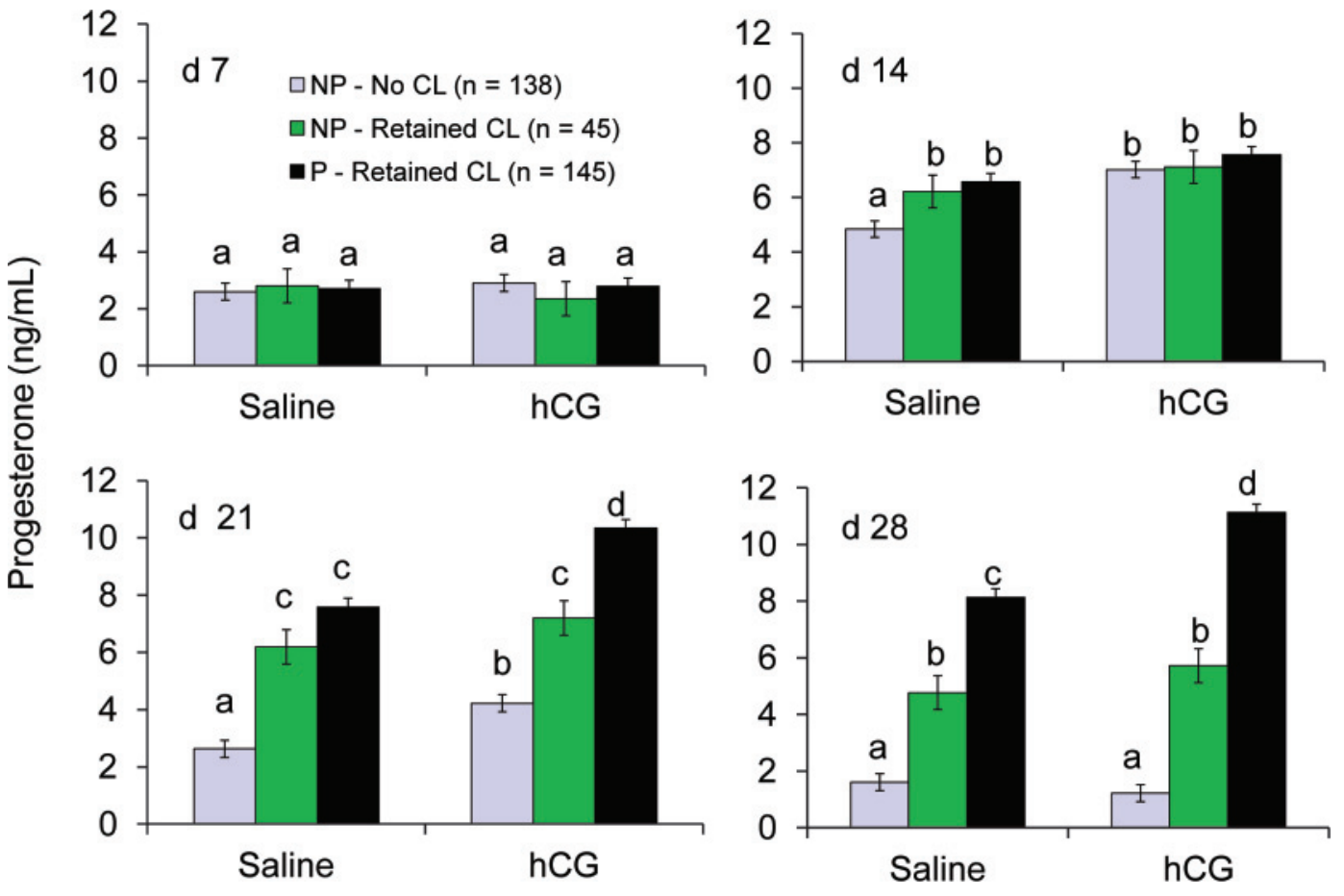

Figure 3. Concentrations of progesterone on d 7, 14, 21, and 28 after GnRH-AI treatment in cows whose (1) original corpus luteum (CL) regressed before d 28 after first AI and were not pregnant (NP) on d 32 (NP-no CL), (2) original CL were retained until d 28 but were not pregnant on d 32 (NP-retained CL), and (3) original CL were retained until d 28 and were pregnant (P) on d 32. Bars with different letters (a-c) within day differ $(P \leq 0.05)$. Error bars represent least squares means \pm standard error. Color version available in the online PDF.

\section{DISCUSSION}

One of the objectives of the present study was to determine characteristics of luteal structures (size, number, and stayability) formed in response to hCG administered on d 7 after AI (first service) in lactating dairy cows. Previous studies in dairy cows have reported similar frequencies of newly formed post-AI luteal structures when hCG was administered at doses ranging from 1,000 to 3,300 IU (Santos et al., 2001; Stevenson et al., 2007; Buttrey et al., 2010). When administered on d 5 after estrus or between d 5 and 9 after AI, formation of new luteal structures in response to hCG ranged from 60 to $75 \%$ (Santos et al., 2001; Stevenson et al., 2007). Frequency of hCG-induced luteal structures in the present study was consistent with the findings of the latter 2 studies. Incidence of $\geq 2$ new luteal structures in our study $(17.2 \%)$ was independent of the number of pretreatment CL and pregnancy status but was slightly less than that reported in other lactating dairy cows (24.8\%; Galvão et al., 2006). Although the level of milk production was not associated with ovulatory response to hCG (Santos et al., 2001), cows enrolled in the present study averaged more than $46 \mathrm{~kg}$ of ECM per day, and those producing greater than $46 \mathrm{~kg}$ of ECM were less likely to form new luteal structures after to hCG. Less likely response to hCG in higher-producer cows may indicate that factors associated with greater milk yield (e.g., greater DMI, geno-

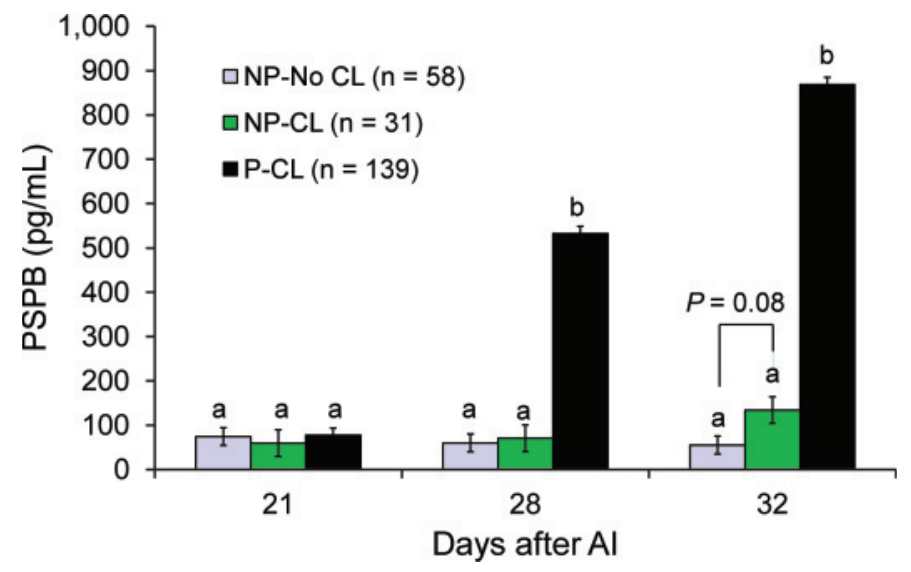

Figure 4. Concentrations of pregnancy-specific protein B (PSPB) on d 21,28 , and 32 after AI in cows whose (1) original corpus luteum (CL) regressed before d 28 after first AI and were not pregnant (NP) on d 32 (NP-no CL), (2) original CL were retained until d 28 but were not pregnant on d 32 (NP-retained CL), and (3) original CL were retained until d 28 and were pregnant $(\mathrm{P})$ on $\mathrm{d} 32$. Bars with different letters $(\mathrm{a}, \mathrm{b})$ within day differ $(P \leq 0.05)$. Error bars represent least squares means \pm standard error. Color version available in the online PDF. 
type, and metabolic efficiencies) may suppress ovarian responses to hCG. In contrast, spontaneous multiple ovulation was associated positively with the level of milk production (Fricke and Wiltbank, 1999).

The present study demonstrated that the appearance of new luteal structures at a dose of 1,000 IU of hCG was similar in pregnant and nonpregnant cows when 1 pretreatment CL was present, but when 2 or more CL were present, the frequency of new luteal structure formation decreased from more than $50 \%$ ( 51.7 to $56.2 \%$ ) to $17 \%$ (16.7 to $17.2 \%$; Table 1 ). This lesser response to hCG was independent of pregnancy status but related to greater endogenous progesterone concentrations in cows with more pretreatment CL, which agrees with our previous observations in cows treated with hCG at later stages of pregnancy (d 26 to 71; Stevenson et al., 2008). In nonpregnant cows that were treated with hCG or GnRH as part of a resynchronization program, incidence of new luteal structure formation was affected by treatment, pretreatment progesterone status by treatment interaction, and number of pretreatment CL (Buttrey et al., 2010). Use of GnRH was more effective than hCG in cows with reduced $(<1 \mathrm{ng} / \mathrm{mL})$ progesterone concentrations, whereas hCG (1,000 IU) was more effective than GnRH in cows with progesterone concentrations $\geq 1 \mathrm{ng} / \mathrm{mL}$ (Buttrey et al., 2010).

Concentrations of progesterone were elevated by hCG and pregnancy status compared with saline controls and lack of pregnancy in the present study, respectively, corroborating similar reports in lactating dairy cows (Santos et al., 2001; Galvão et al., 2006; Stevenson et al., 2007) and in dairy heifers (Schmitt et al., 1996a). Although we did not detect increased progesterone in cows in which hCG failed to produce new luteal structures, previous studies reported that progesterone secretion by original CL was enhanced (Stevenson et al., 2007). This enhancement in progesterone was attributed to the ability of $\mathrm{hCG}$ to induce premature differentiation of small luteal cells to large luteal cells, which was demonstrated morphometrically in sheep (Farin et al., 1988). Despite the lack of progesterone enhancement, the volume of the original CL was enhanced by hCG in the present study (Table 2).

Loss of original CL in multiple-ovulating cows as well as loss of induced luteal structures is not well documented. A previous study demonstrated that 1,000 IU of hCG induced accessory luteal structures in $50 \%$ of pregnant lactating cows between d 26 and 71 of pregnancy (Stevenson et al., 2008). Cows with new luteal structures had greater serum concentrations of progesterone at 1 and 2 wk after treatment compared with those without induced luteal structures, but approximately one-third of the new luteal structures regressed sometime during the 4 -wk post-hCG study period. The majority of those disappearing luteal structures were gone by 2 wk after their induction, and regression occurred more often on the left ovary and contralateral to the CL of pregnancy ( 53.2 vs. $22 \%$ ). Consistent with the previous findings for pregnant cows treated after $\mathrm{d}$ 26 of pregnancy (Stevenson et al., 2008), greater than half of the loss of luteal structures induced earlier in pregnancy $(\mathrm{d} 7)$ in the present study occurred after $d$ 28 , and almost all of those structures were contralateral to the original CL.

Incidence of spontaneously forming new luteal structures in saline cows $(2.4 \%)$ is not unique to the present study. Spontaneous luteal structures were detected in 9 of $133(6.8 \%)$ pregnant controls between d 26 and 71 of pregnancy (Stevenson et al., 2008). In another study, pregnancy maintained in 40 lutectomized beef cows by replacement progesterone was supplied by 2 progesterone inserts (controlled internal drug release inserts) that were first inserted on d 28 and replaced every 5 d through d 53 (Starbuck et al., 2006). After d 34 and before d 38, a spontaneous new luteal structure was identified by ultrasonography in 5 cows, in each case on the ovary ipsilateral to the uterine horn of pregnancy. Concentrations of progesterone in these cows began to increase as early as d 33, exceeding those recorded for the remainder of the cows, to concentrations normally detected in pregnant cows. The new luteal structure and pregnancy were maintained through d 53 in 3 of those 5 cows. The lifespan of the spontaneous luteal structure was transient in the remaining 2 cows, and it was no longer visible by ultrasonography on d 40; 1 cow lost pregnancy and the other maintained pregnancy to d 53.

Although more saline- than hCG-treated cows returned to estrus from 18 to $25 \mathrm{~d}$ (Table 5 ), the duration of the estrous cycles of both saline and hCG-treated cows were equally prolonged (Table 6). Part of this proportional difference in return to estrus was associated with elevated concentrations of progesterone in hCGtreated cows on d 14 and 21. Elevated progesterone may have enhanced the pregnancy signal in marginal embryos and caused more hCG-treated cows to have prolonged intervals to reinsemination. This potential enhancement, however, did not persist beyond d 21 after AI because similar proportions of cows (25\%; Table 6 ) in both treatments retained at least 1 original CL to d 28 but were not pregnant at d 28 or 32 .

Variability and difference in duration of postpartum estrous cycles is evident between early nonbreeding cycles and those that occur after an unsuccessful AI (Stevenson, 2011). Furthermore, based on comparisons of interovulatory intervals monitored by patterns of 
milk progesterone for British Friesian (1975 to 1982) and Holstein-Friesian (1995 to 1998) cows in the UK (Royal et al., 2000), estrous-cycle duration has changed over time. In that study, $38.8 \%$ of 1975 - to 1982-period dairy cows had cycle durations of 21 through $24 \mathrm{~d}$ and $24.2 \%$ were greater than $22 \mathrm{~d}$. In contrast, $46.1 \%$ of the 1995- to 1998-period dairy cows had cycle durations of 21 through $24 \mathrm{~d}$ and $42 \%$ were greater than $22 \mathrm{~d}$. In comparison, in Holstein and Jersey cows in the United States (1977 to 1978), 47\% had cycle durations of 21 through $24 \mathrm{~d}$ and $47.1 \%$ were greater than $22 \mathrm{~d}$ (Stevenson, 2011). The increase in interovulatory duration from 20.2 to $22.3 \mathrm{~d}$ in the UK study (Royal et al., 2000) was associated with delayed luteolysis (6.4 to $16.8 \%$ ) and increased mean luteal phase (12.9 to $14.8 \mathrm{~d}$ ).

The fact that $25 \%$ of cows in the present study retained at least 1 original CL to d 28 after timed AI indicates that some of the previously observed long estrous cycles were associated with early embryo loss after pregnancy recognition. Because only 6 of 31 had elevated PSPB on d 32 and only 2 of 6 had elevated PSPB on d 28 and 32 may indicate that these embryos were late developing. Although these embryos may have been sufficiently viable to prevent luteolysis by secreting adequate amounts of IFN- $\tau$ and survived variously beyond $\mathrm{d} 21$, they lacked the ability to produce adequate concentrations of PSPB by the trophectoderm binucleate cells (Sasser et al., 1989). The suggestion of early embryo loss also is supported by our observation that these nonpregnant cows with retained CL had progesterone concentrations intermediate between those in nonpregnant cows that returned to estrus by $\mathrm{d}$ 21 and those in cows diagnosed as pregnant on d 28 or 32 (Figure 3). Evidence that some of these nonpregnant retained-CL cows were pregnant also was supported by elevated concentrations of PSPB on d 32 (Figure 4).

Many pregnancy losses occur before pregnancy recognition, but in high-producing lactating dairy cattle, substantial losses continue to occur up to 42 to $56 \mathrm{~d}$ after insemination (Santos et al., 2004). Several factors affect pregnancy losses in cattle, such as compromised oocytes, resulting in poorly developed embryos incapable of cross-talking with the endometrial epithelial cells, to inadequate uterine environment and infectious agents, resulting in death of the embryo from undernourishment (Santos et al., 2004). Other studies indicated anovulation or anestrus, metabolic status of the cow, some dietary ingredients, as well as occurrence of diseases, predispose the cow to experience embryonic and fetal death (Santos et al., 2004). Although some insemination protocols might affect embryo survival, when timed AI has been implemented properly, it has not influenced embryonic or fetal death in cattle (Santos et al., 2004).
Fewer pregnancies per AI at d 32 and 60 were observed in hCG- than saline-treated cows, but this reduction was wholly detected in hCG-treated cows with only 1 original CL that also failed to form new luteal structures in response to hCG. In contrast, recent studies demonstrated an approximately 5- to 7-percentage unit advantage in conception rate for hCG-treated cows at first service (Santos et al., 2001; Shabankareh et al., 2010). These responses occurred at doses of 3,000 to $3,300 \mathrm{IU}$ of hCG. In contrast, a recent report of lactating dairy cows treated with 2,500 IU of hCG on d 4 after timed AI at either first (33.6\% of total services) or more postpartum services failed to detect a positive pregnancy outcome (Fischer-Tenhagen et al., 2010). Generally, the positive pregnancy outcomes in lactating cows did not occur during summer (Schmitt et al., 1996b; Santos et al., 2001); however, a recent report showed improved fertility for hCG-treated, first-service cows enrolled during summer and winter in western Iran (Shabankareh et al., 2010).

In the largest study conducted to date at 5 locations consisting of 1,422 cows (Stevenson et al., 2007), differences in conception rates were greatest in second-lactation cows with only small increases for first-, third-, or greater-lactation cows. When insemination number was controlled before $\mathrm{hCG}$ treatment and comparisons were made between hCG and control cows for first services or all repeat $(\geq 2)$ services (Stevenson et al., 2007 ), conception rates were identical for cows treated after first service $[33.4(\mathrm{n}=287)$ vs. $33.2 \%(\mathrm{n}=277)]$, respectively, whereas for cows inseminated more than once before treatment (repeat breeders), a trend for increased conception rate for hCG-treated compared with control cows was reported [31.6 $(\mathrm{n}=477)$ vs. $25.3 \%$ (n $=431$ )], respectively. In the present study, the poorest pregnancy per AI at d 32 and 60 occurred in cows with 1 original CL that failed to respond to hCG (Table 3 ). Pregnancy per AI in this subgroup of cows indicated that hCG may have had a negative effect on fertility because in all other combinations of original CL and new luteal structures, cows receiving hCG had numerically greater pregnancy per AI. We have no explanation for this apparent negative effect of hCG.

Although 1,000 IU of hCG induced new luteal structure formation and increased progesterone concentration in the present study, which corroborated similar findings in other studies when 3,300 IU hCG were administered (Santos et al., 2001; Stevenson et al., 2007), no increased pregnancy outcome was observed consistently in all luteal pre- and posttreatment combinations (Table 3). Lack of increased pregnancy outcome at first service may have occurred because the dose of the hCG was insufficient in the present study (1,000 IU) as compared with $3,300 \mathrm{IU}$ or greater in other studies 
(Santos et al., 2001; Stevenson et al., 2007), indicating that the mechanism of action of $\mathrm{hCG}$ for improved fertility may be independent of increased progesterone and more luteal structures associated with the smaller dose of hCG. This is further corroborated by the fact that GnRH administration in the Stevenson et al. (2007) study increased formation of new structures and progesterone concentration but also failed to increase pregnancy outcomes.

In summary, treatment with hCG increased the number and volume of luteal structures and progesterone concentration but had no positive effect on pregnancy outcome at first services, consistent with some reports in the literature. Retention of original luteal tissue in nonpregnant cows to d 28 after AI was independent of hCG or saline treatment, and indicated that pregnancy had been initiated but failed, as verified by attenuated concentrations of progesterone and PSPB. Greater than half of the loss of luteal structures induced early in pregnancy $(\mathrm{d} 7)$ in the present study occurred after $\mathrm{d}$ 28 , and almost all of those structures were contralateral to the original CL.

\section{ACKNOWLEDGMENTS}

We thank Garth Sasser, Joshua Branen, and Jeremy Howard (Biotracking LLC, Moscow, ID) for their interest in this study and for assaying samples for PSPB concentration. We acknowledge Mike Scheffel and other employees at the Kansas State University Dairy Teaching and Research Center (Manhattan) for their care of experimental cows. We thank Colleen Hill (Department of Animal Sciences and Industry, Kansas State University, Manhattan) for her laboratory expertise in managing blood samples and conducting all progesterone RIA. We thank Andrew Skidmore and Schering-Plough Intervet Animal Health (Kenilworth, NJ) for donation of the Chorulon product and Select Sires Inc. (Plain City, $\mathrm{OH}$ ) for partial funding of this study.

\section{REFERENCES}

Breuel, K. F., J. C. Spitzer, and D. M. Henricks. 1989. Systemic progesterone concentration following human chorionic gonadotropin administration at various times during the estrous cycle in beef heifers. J. Anim. Sci. 67:1564-1572.

Buttrey, B. S., M. G. Burns, and J. S. Stevenson. 2010. Ovulation and pregnancy outcomes in response to human chorionic gonadotropin before resynchronized ovulation in dairy cattle. Theriogenology 73:449-459.

Eduvie, L. Q., and B. E. Seguin. 1982. Corpus luteum function and pregnancy rate in lactating dairy cows given human chorionic gonadotropin at middiestrus. Theriogenology 17:415-422.

Farin, C. E., C. L. Moeller, H. Mayan, F. Gamboni, H. R. Sawyer, and G. D. Niswender. 1988. Effect of luteinizing hormone and human chorionic gonadotropin on cell populations in the ovine corpus luteum. Biol. Reprod. 38:413-421.
Fischer-Tenhagen, C., G. Thiele, W. Heuwieser, and B. A. Tenhagen. 2010. Efficacy of a treatment with hCG 4 days after AI to reduce pregnancy losses in lactating dairy cows after synchronized ovulation. Reprod. Domest. Anim. 45:468-472.

Fricke, P. M., and M. C. Wiltbank. 1999. Effect of milk production on the incidence of double ovulation in dairy cows. Theriogenology 52:1133-1143.

Galvão, K. N., J. E. P. Santos, A. C. Coscioni, S. O. Juchem, R. C. Chebel, W. M. Sischo, and M. Villaseñor. 2006. Embryo survival from gossypol-fed heifers after transfer to lactating cows treated with human chorionic gonadotropin. J. Dairy Sci. 89:2056-2064.

Howard, H. J., and J. H. Britt. 1990. Prostaglandin $\mathrm{F}_{2 \alpha}$ causes regression of an hCG-induced corpus luteum before day 5 of its life-span in cattle. J. Reprod. Fertil. 90:245-253.

Mann, G. E., and G. E. Lamming. 1999. The influence of progesterone during early pregnancy in cattle. Reprod. Domest. Anim. 34:269-274.

Mann, G. E. G. E. Lamming, R. S. Robinson, and D. C. Wathes. 1999. The regulation of interferon- $\tau$ production and uterine hormone receptors during early pregnancy. J. Reprod. Fertil. 54(Suppl. 1):317-328.

Niswender, G. D., J. L. Juengel, P. J. Silva, M. K. Rollyson, and E. W. McIntush. 2000. Mechanisms controlling the function and life span of the corpus luteum. Physiol. Rev. 80:1-29.

Niswender, G. D., R. H. Schwall, T. A. Fitz, C. E. Farin, and H. R. Sawyer. 1985. Regulation of luteal function in domestic ruminants: New concepts. Recent Prog. Horm. Res. 41:101-151.

NRC. 2001. Nutrient Requirements of Dairy Cattle. 7th rev. ed. Natl Acad. Sci., Washington, DC.

Pursley, J. R., R. W. Silcox, and M. C. Wiltbank. 1998. Effect of time of artificial insemination of pregnancy rates, calving rates, pregnancy loss, and gender ratio after synchronization of ovulation in lactating dairy cows. J. Dairy Sci. 81:2139-2144.

Rajamahendran, R., and P. C. Sianangama. 1992. Effect of human chorionic gonadotropin on dominant follicles in cows: Formation of accessory corpora lutea, progesterone production and pregnancy rates. J. Reprod. Fertil. 95:577-584.

Royal, M. D., A. O. Darwash, A. P. F. Flint, R. Webb, J. A. Woolliams, and G. E. Lamming. 2000. Declining fertility in dairy cattle: Changes in traditional and endocrine parameters of fertility. Anim. Sci. 70:487-501.

Santos, J. E. P., W. W. Thatcher, R. C. Chebel, R. L. A. Cerri, and K. N. Galvão. 2004. The effect of embryonic death rates in cattle on the efficacy of estrus synchronization programs. Anim. Reprod. Sci. 82-83:513-535.

Santos, J. E. P., W. W. Thatcher, L. Pool, and M. W. Overton. 2001. Effect of human chorionic gonadotropin on luteal function and reproductive performance of high-producing lactating Holstein dairy cows. J. Anim. Sci. 79:2881-2894.

Sasser, R. G., J. Crock, and C. A. Ruder-Montgomery. 1989. Characteristics of pregnancy-specific protein B in cattle. J. Reprod. Fertil. Suppl. 37:109-113.

Schmitt, É. J.-P., C. M. Barros, P. A. Fields, M. J. Fields, T. Diaz, J. M. Kluge, and W. W. Thatcher. 1996a. A cellular and endocrine characterization of the original and induced corpus luteum after administration of a gonadotropin-releasing hormone agonist or human chorionic gonadotropin on day five of the estrous cycle. J. Anim. Sci. 74:1915-1929.

Schmitt, E. J.-P., T. Diaz, C. M. Barros, R. L. de la Sota, M. Drost, E. W. Fredriksson, C. R. Staples, R. Thorner, and W. W. Thatcher. 1996b. Differential response of the luteal phase and fertility in cattle following ovulation of the first-wave follicle with human chorionic gonadotropin or an agonist of gonadotropin-releasing hormone. J. Anim. Sci. 74:1074-1083.

Shabankareh, H. K., M. Zandi, and M. Ganjali. 2010. First service pregnancy rates following post-AI use of hCG in Ovsynch and Heatsynch programmes in lactating dairy cows. Reprod. Domest. Anim. 45:711-716.

Starbuck, M. J., D. H. Poole, and E. J. Inskeep. 2006. Ability of induced corpora lutea to maintain pregnancy from the third month of gestation to term in cattle. Theriogenology 66:383-386. 
Stevenson, J. S. 2011. Long estrous cycles present breeding challenges. Hoard's Dairyman 156:569.

Stevenson, J. S., S. L. Pulley, and H. I. Mellieon Jr. 2012. Prostaglandin $\mathrm{F}_{2 \alpha}$ and gonadotropin-releasing hormone administration improve progesterone status, luteal number, and proportion of ovular and anovular dairy cows with corpora lutea before a timed artificial insemination program. J. Dairy Sci. 95:1831-1844.

Stevenson, J. S., D. E. Tenhouse, M. A. Portaluppi, D. R. Eborn, S. Kacuba, and J. M. DeJarnette. 2007. Interventions after artificial insemination: Conception rates, pregnancy survival, and ovarian responses to gonadotropin-releasing hormone, human chorionic gonadotropin, and progesterone. J. Dairy Sci. 90:331-340.

Stevenson, J. S., S. M. Tiffany, and E. K. Inskeep. 2008. Maintenance of pregnancy in dairy cattle after treatment with human chorionic gonadotropin or gonadotropin-releasing hormone. J. Dairy Sci. 91:3092-3101.

Thatcher, W. W., F. Moreira, J. E. P. Santos, R. C. Mattos, F. L. Lopes, S. M. Pancarci, and C. A. Risco. 2001. Effects of hormonal treatments on reproductive performance and embryo production. Theriogenology 55:75-89.

Thatcher, W. W., C. R. Staples, G. Danet-Desnoyers, G. Oldick, and E.-P. Schmidt. 1994. Embryo health and mortality in sheep and cattle. J. Anim. Sci. 72(Suppl. 3):16-30.

Vasconcelos, J. L. M., R. W. Silcox, G. J. M. Rosa, J. R. Pursley, and M. C. Wiltbank. 1999. Synchronization rate, size of the ovulatory follicle, and pregnancy rate after synchronization of ovulation beginning on different days of the estrous cycle in lactating dairy cows. Theriogenology 52:1067-1078. 